\title{
TAFSIR YURIDIS FILOSOFIS PASAL 56 AYAT 1 UNDANG-UNDANG NOMOR 39 TAHUN 2014 TENTANG PERKEBUNAN
}

\author{
Zainul Akmal \\ Fakultas Hukum, Universitas Riau \\ Email: zainulakmal@lecturer.unri.ac.id
}

Info Artikel:

Diterima: 09 Agustus 2021

| Disetujui: 09 Agustus 2021

| Dipublikasikan: 12 Agustus 2021

\begin{abstract}
Abstrak
Pasal 108 junto Pasal 56 ayat (1) UU No. 39 Tahun 2014 tentang Perkebunan dijadikan alat oleh penegak hukum untuk menangkap dan menghukum pembakar lahan. Sebagian pelaku yang ditangkap dan dihukum adalah petani lokal yang miskin dan masyarakat yang membakar di pekarangan rumahnya. Jurnal ini bertujuan untuk mengetahui, arah kebijakan negara terhadap pelarangan membuka lahan dengan cara membakar dan orang atau badan hukum yang dikategorikan sebagai pelaku usaha perkebunan dalam Pasal 56 ayat (1) UU Perkebunan. Hasil dari kajian menemukan bahwa, Usaha Perkebunan dilakukan dengan berwawasan lingkungan yang memiliki relevansi dengan UU No. 32 Tahun 2009 tentang PPLH dan pelaku usaha perkebunan yang dilarang membuka lahan dengan cara membakar bukanlah pekebun melainkan perusahaan perkebunan.
\end{abstract}

Kata Kunci: Perkebunan, Pekebun dan Perusahaan Perkebunan

\section{PHILOSOPHICAL JURIDIC INTERPRETATION ARTICLE 56 SECTION 1 LAW NUMBER 39 OF 2014 CONCERNING PLANTATIONS}

\begin{abstract}
Article 108 junto Article 56 paragraph (1) of Law No. 39 of 2014 on Plantation is used as a tool by law enforcement to arrest and punish arsonists. Some of the perpetrators arrested and convicted were poor local farmers and people who burned in the yard of his house. This journal aims to determine the direction of state policy towards the prohibition of clearing land by burning and people or legal entities categorized as plantation businesses in Article 56 paragraph (1) of the Plantation Law. The results of the study found that, Plantation Business is carried out with environmental insights that have relevance to Law No. 32 of 2009 on Environmental Protection and Management and plantation businesses that are prohibited from clearing land by burning are not planters but plantation companies.
\end{abstract}

Keywords: Plantations, Planters and Plantation Companies

Jurnal Gagasan Hukum Vol. 03 | No.01 | Juni 2021 | 


\section{A. PENDAHULUAN}

Beberapa daerah di Indonesia setelah mengalami berulang kali bencana asap, penegak hukum berusaha untuk menegakkan hukum lebih maksimal. Tekanan dari publik baik dari dalam negeri maupun dari luar negeri semakin kuat. Adanya asap, disebabkan adanya api, dan api hadir karena proses pembakaran. Proses pembakaran yang tidak manusiawi akan menimbulkan kerusakan lingkungan. Dampak dari kerusakan ini tidak hanya akan dirasakan oleh rakyat Indonesia saja, namun seluruh dunia.

Penegak hukum berusaha menangkap pelaku pembakaran lahan. penangkapan tidak memperdulikan luas lahan yang terbakar dan status dari pelaku pembakarannya dan budaya masyarakat setempat. Akibat dari penegakan hukum tersebut, sebagian yang ditangkap adalah petani miskin dan sebagiannya lagi bukan petani tetapi orang yang membersihkan pekarangan rumahnya dengan cara membakar. Misalnya dalam kasus Irwan di Kabupaten Rokan Hulu dan Rustam di Kabupaten Meranti.

Berdasarkan fakta persidangan ${ }^{1}$ di Pengadilan Negeri Rokan Hulu, Irwan als Iwan bin Zainal adalah seorang anak

\footnotetext{
${ }^{1}$ Kejaksaan Negeri Rokan Hulu, "P-29, Surat Dakwaan No. Reg. Perkara.: PDM148/PSP/11/2019, Lihat Juga Kejaksaan Negeri Rokan Hulu, P-42, Surat Tuntutan No. Reg. Perk.: PDM-148/Psp/11/2019”' (Rokan Hulu, 2019).
}

berusia 20 tahun yang menjadi kepala keluarga karena Ibunya Janda. Iwan bekerja sebagai petani yang melakukan pembakaran lahan seluas 0,3 hektar. Pembakaran dilakukan dengan cara menumpukkan kayu tunggul dan ranting-rangting dalam beberapa tumpuk, dalam budaya Melayu Rokan disebut dengan mumorun. Tujuan pembakaran untuk menanam padi dan sayur-sayuran. Lahan yang diolah iwan bukanlah milik pribadinya, melainkan meminjam kepada tetangganya.

Berdasarkan fakta persidangan ${ }^{2}$ di Pengadilan Negeri Rustam Bin. Alm. Kartawirya membakar sampah di tanah pekarangan rumahnya. Pekarang tersebut ditumbuhi tanaman musiman secara liar, seperti kelapa, pisang dan pinang yang ditanam sebagai batas sempadan tanah. Tujuan Rustam untuk mempersiapkan acara syukuran aqikah anaknya yang baru lahir. Metode yang digunakan adalah mumoron. Mengumpulkan sampah lalu diletakkan pada tunggul kayu, dan sudah terlebih dahulu dibersihkannya sekeliling tunggul kayu tersebut. Pekerjaan rustam adalah buruh.

Api yang membakar sampah tersebut akhirnya menjalar dikarenakan ada sesuatu

\footnotetext{
${ }^{2}$ LBH PEKANBARU, "Resume Perkara Pidana Nomor : 187/Pid.B/2020/PN.Bls An Terdakwa Rustam Bin. Alm. Kartawirya Pada Pengadilan Negri Bengkalis Oleh LBH Pekanbaru, Lihat Juga Kejaksaan Negeri Kepulauan Meranti, P-42, Surat Tuntutan No Reg Perkara : PDM- 57 /SLP/ 04 12020" (Pekanbaru, 2020).
} 
yang meletus. Percikan api disebabkan letusan disambut oleh angin puting beliung dan semak-semak yang berada didekat Rustam membakar, karena baru diracun dan sudah menguning kering sehingga api menjalar. Jarak api dengan rumah Rustam sekitar 10 meter. Luas tanah rustam secara keseluruhan termasuk areal terbakar, rumah dan pekarangan yang tidak tebakar $1.500 \mathrm{M}$ persegi. Luas tanah yang terbakar sekitar 10x15 Meter yaitu seluas 150M persegi.

Berdsarkan hal diatas Iwan dan Rustam dituntut dengan dakwaan Pasal 108 jo Pasal 56 ayat (1) UU No. 39 Tahun 2014 tentang Perkebunan. ${ }^{3} \quad$ Jaksa Penuntut Umum (JPU) bependapat bahwa Iwan dan Rustam telah melakukan tindak pidana sebagai pelaku usaha perkebunan yang mebuka dan/atau mengolah lahan dengan cara membakar yang ada pada Pasal 108 jo Pasal 56 ayat (1). Putusan masing-masing pengadilan menyatakan Iwan dan Rustam bersalah.

Dua tuntutan JPU menyebut para terdakwa sebagai pelaku usaha perkebunan dan melakukan pembukaan dan/atau pengelolaan lahan dengan cara membakar. Tuntutan JPU menimbulkan beberapa pertanyaan, seperti apakah sama pelaku usaha perkebunan dengan buruh yang memiliki tanaman musiman pada pekarangan rumahnya? Apakah sama lahan

\footnotetext{
3 Undang-Undang Republik Indonesia Nomor 39 Tahun 2014 tentang Perkebunan
}

dengan skala tertentu yang adalam UU Perkebunan dengan pekarangan rumah yang ditumbuhi tanaman musiman? Apakah petani miskin yang meminjam tanah tetangganya untuk bercocok tanam sama dengan lahan yang dimaksud dalam UU perkebunan? Apakah pelaku usaha perkebunan yang ada dalam UU Perkebunan sama dengan petani yang akan menanam tanaman variates lokal seperti padi dan sayur sayuran?

Oleh sebab itu perlu menurut penulis untuk meneliti dan menjelaskan hasil penelitian penulis tentang Tafsir Yuridis Filosofis "pelaku usaha perkebunan dan luas lahan perkebunan skala tertentu" dalam Undang-Undang Nomor 39 Tahun 2014 tentang Perkebunan.

Berdasarkan latar belakang diatas, maka dapat dirumuskan beberapa masalah yang akan dibahas dalam kajian konseptual ini, sebagai berikut:

(1). Politik hukum UU No. 39 Tahun 2014 tentang Perkebunan dan kaitannya dengan lingkungan hidup

(2). Siapakah yang dimaksud pelaku usaha perkebunan dalam Pasal 56 ayat (1) UU Perkebunan?

Berdasarkan perumusan masalah di atas, kanjian ini bertujuan sebagai berikut: (1). Untuk mengetahui arah kebijakan negara terhadap pelarangan membuka lahan dengan cara membakar. (2). Untuk mengetahui orang atau badan hukum yang 
dikategorikan sebagai pelaku usaha perkebunan dalam Pasal 56 ayat (1) UU Perkebunan, sehingga bisa dijerat dengan Pasal 108 UU Perkebunan.

\section{B. METODE PENELITIAN}

Spesifiksi penelitian menggunakan jenis penelitian deskriptif normatif metode kualitatif pendekatan filosofis dengan teknik pengumpulan data yang bersifat pustaka atau dokumen dan melakukan analisis kualitatif deduktif.

Penelitian hukum yuridis normatif $^{4}$ atau doktriner yang juga disebut sebagai penelitian perpustakaan atau studi dokumen, karena lebih banyak dilakukan terhadap data yang bersifat sekunder yang ada di perpustakaan ${ }^{5}$. Penelitian deskriptif normatif yang menggunakan data skunder seperti bahan hukum primer berupa peraturan perundang-undangan, bahan hukum sekunder berupa hasil penelitian dan pendapat ahli, dan bahan hukum tersier berupa kamus hukum serta dokumendokumen lain yang memiliki hubungan dengan penelitian ini.

Metode penelitian kualitatif bisa menggunakan dua strategi analisis data

\footnotetext{
${ }^{4}$ Adrian Faridhi, "Penguji Peraturan Perundang-

Undangan Tunggal Keniscayaan,' Jurnal

Mercatoria 10, no. 2 (2017): 180-96,

https://doi.org/10.31289/mercatoria.v10i2.1202.

${ }^{5}$ Ediwarman, "Monograf Metodologi Penelitian

Hukum (Panduan Penelitian Tesis Dan Disertasi)"

(Universitas Muhammadiyah Sumatera Utara,

2010).
}

yang sering digunakan bersama-sama secara terpisah yaitu model strategi analisis deskriptif kualitatif dan atau model strategi analisis verifikatif kualitatif $^{6}$. Oleh sebab itu metode pendekatan filosofis adalah pilihan yang baik digunakan dalam penelitian kualitatif deskriptif normatif agar keadilan bias ditegakkan. Sebab keadilan adalah pembahasan yang subtansi dalam filsafat hukum ${ }^{7}$.

Teknik pengumpulan data dengan cara melakukan tinjaun pustaka terhadap berbagai bahan hokum mulai dari primer hingga tersier. Analisis data adalah proses menyusun data agar data tersebut dapat ditafsirkan ${ }^{8}$. Dalam hal ini, analisis yang digunakan adalah analisis data kualitatif yaitu data yang tidak bisa diukur atau dinilai dengan angka secara langsung 9 .

\section{HASIL DAN PEMBAHASAN}

Pada Hasil dan Pembahasan memuat uraian tentang analisis hasil penelitian

\footnotetext{
${ }^{6}$ Burhan Bungin, Analisis Data Penelitian Kualitatif, Pemahaman Filosofis Dan Metodologis Ke Arah Penguasaan Model Aplikasi (Jakarta: Raja Grafindo Persada, 2003).

${ }^{7}$ Suwardi Sagama, "Analisis Konsep Keadilan, Kepastian Hukum Dan Kemanfaatan Dalam Pengelolaan Lingkungan," MAZAHIB: Jurnal Pemikiran Hukum Islam XV, no. 1 (December 15, 2016): 20-41, https://doi.org/10.21093/mj.v15i1.590.

${ }^{8}$ Dadang Kahmad, Metode Penelitian Agama (Bandung: CV Pustaka Setia, 200AD).

${ }^{9}$ Tatang M. Amirin, Menyusun Rencana Penelitian (Jakarta: PT Raja Grafindo Persada, 1995).
} 
untuk memberikan jawaban/solusi terhadap masalah penelitian. Apabila terdapat rincian sesuai dengan permasalahan yang dibahas, maka dapat menggunakan penulisan sub bab seperti di bawah ini.

\section{Politik Hukum UU Perkebunan Dan} Hubungan Dengan Kelestarian

\section{Lingkungan Hidup}

Undang-Undang Nomor 39 Tahun 2014 Tentang Perkebunan

(UU

Perkebunan) melarang membuka lahan dengan cara membakar, sebagaimana di atur dalam Pasal 56 Ayat (1) "Setiap Pelaku Usaha Perkebunan dilarang membuka dan/atau mengolah lahan dengan cara membakar". Apabila larangan ini tidak ditaati, maka bagi yang melanggarnya akan dihadapkan dengan Pasal 108 "Setiap Pelaku Usaha Perkebunan yang membuka dan/atau mengolah lahan dengan cara membakar sebagaimana dimaksud dalam Pasal 56 ayat (1) dipidana dengan pidana penjara palinglama 10 (sepuluh) tahun dan denda paling banyak $\mathrm{Rp}$ 10.000.000.000,00 (sepuluh miliar rupiah)".

Pasal 6 ayat 1 menimbulkan suatu pertanyaan, mengapa diatur larangan membuka dan mengolah lahan dengan cara membakar? Apakah larangan membakar hadir karena alasan perkebunan atau alasan lain yang berkaitan dengan UU lainnya? Oleh sebab itu perlu melihat politik hukum dari UU Perkebunan itu sendiri untuk melihat keterkaiatan antara larangan membakar dengan perkebunan.

Perkebunan adalah salah satu yang memiliki potensi besar dalam membangun perekonomian Indonesia untuk mencapai kemakmuran dan kesejahteraan. Sebagian rakyat Indonesia memiliki usaha perkebunan untuk memenuhi kehidupan sehari-harinya. Indonesia sebagai negara agraris dan subur tentu sangat berpotensi besar dalam mengembangkan usaha perkebunan. Selayaknya pemerintah Indonesia perlu memperhatikan pengelolaan luas lahan perkebunan dan pelaku usaha perkebunan.

Usaha perkebunan menarik perhatian negara, kelompok tertentu dan orang asing untuk bisa ikut serta. Keuntungan yang menggiurkan membuat daya tarik yang memikat. Terlihat ada beberapa perusahaan milik negara yang bergerak dibidang perkebunan, salah satunya PT. Perkebunan Nusantara V. Perusahaan yang berbadan hukum privat milik swasta juga banyak bergerak dibidang perkebunan, salah satunya PT. Smart. Tbk (Sinar Mas Agribussines and Food).

UU Perkebunan hadir dalam rangka memenuhi kedaulatan rakyat Republik Indonesia. Undang-Undang Dasar Negara Republik Indonesia Tahun 1945 (UUD 1945) adalah bentuk kedaulatan rakyat. Indonesia selain menganut kedaulatan 
rakyat juga menganut kedaulatan hukum, oleh sebab itu bentuk nyata kedaulatan rakyat Indonesia adalah UUD 1945 itu sendiri.

Selain menganut dua kedaulatan di atas, Indonesia juga menganut kedaulatan Tuhan. Hukum dan kehendak rakyat tidak boleh bertentangan dengan kehendak Tuhan. Bangsa Indonesia adalah bangsa yang sangat sadar akan eksistensi Tuhan. Kesadaran ini terlihat didalam kehendak rakyat Indonesia yang menyatakan bahwa "bumi, air dan kekayaan alam yang terkandung dalam wilayah republik Indonesia merupakan anugerah Tuhan Yang Maha Esa”.

Implikasi segala sesuatu yang ada dalam wilayah Indonesia sebagai anugrah Tuhan, maka harus dimanfaatkan dan digunakan untuk makhlukNya dengan baik. Oleh sebab itu negara Indonesia berkewajiban memakmurkan dan mensejahterakan Rakyat Indonesia. Tujuannya agar keadilan sosial bisa dicapai secara sempurna bagi Rakyat Indonesia sebagai bentuk penghambaan terhadap Tuhan dan telah di atur dalam UUD 1945.

Perhatian pemerintah dalam memakmurkan dan mensejahterakan rakyatnya tidak bisa hanya berbentuk tindakan faktual, namun juga dalam bentuk tindakan hukum. Tindakan faktual tanpa tindakan hukum akan menyebabkan penyalahgunaan wewenang. Hal utama yang harus disediakan oleh pemerintah adalah instrumen-instrumen yuridis. Untuk memenuhi amanah rakyat, maka hadirlah UU Perkebunan, agar perkebunan yang diharapkan bisa memakmurkan dan mensejahterakan rakyat Indonesia bisa terwujud.

Dilihat dari hadirnya Undang-Undang Nomor 39 Tahun 2014 tentang Perkebunan adalah ganti dari Undang-Undang Nomor 18 Tahun 2004 tentang Perkebunan. Penggantian tersebut disebabkan sebagai berikut: pertama UU yang lama sudah tidak sesuai dengan dinamika dan kebutuhan hukum masyarakat. Kedua belum mampu memberikan hasil yang optimal. Ketiga belum mampu meningkatkan nilai tambah usaha perkebunan nasional.

Tiga aspek diatas memiliki saling keterkaitan antara satu dengan yang lainnya. Perkebunan yang sehat untuk hasil yang maksimal membutuhkan sudut pandang yang sehat tentang perkebunan, mulai dari pembuat keijakan, menyelenggara kebijakan, hingga yang menegakkan. Dinamika hukum di masyarakat, sebagiannya adalah permasalahan lahan. Sebagian pelaku usaha perkebunan baik milik negara atau swasta bermasalah dengan masyarakat tempatan. Perkebunan yang diharapkan 
memakmurkan dan mensejahterakan rakyat malah membuat kesengsaraan.

Perusahaan perkebunan yang dimodali oleh asing, tentunya sangat berkemungkinan akan menjadi permasalahan. Jika negara tidak mengatur dengan baik keterlibatan asing dalam mengelola perkebunan di Indonesia, maka kedaulatan yang menjadi taruhannya.

Penjajahan gaya baru dimungkinkan hadir dengan metode investasi dan kewenangan dalam menentukan kebijakan perusahaan. Jika dibiarkan, maka rakyat Indonesia hanya akan menjadi penonton terhadap hasil kekayaan alamnya sendiri.

Pemerintah membutuhkan sistem yang baik dan penyelenggara yang baik untuk menjadikan perkebunan sebagai salah satu yang meningkatkan ekonomi rakyat. Sistem yang buruk dengan penyelenggara yang baik tidak akan bisa menjadi efektif, begitu juga sebaliknya jika sistemnya baik tapi penyelenggaranya buruk, apalagi jika dua-duanya buruk.

Pemerintah perlu melakukan pengawasan yang “ekstra baik" dalam melakukan pengawasan terhadap pelaku usaha perkebunan. Tidak peduli pelaku usaha itu orang pribadi atau perusahaan yang dimiliki oleh swasta, swasta asing ataupun negara sendiri. Tidak tertutup kemungkinan ada oknum yang akan melakukan perbuatan busuk, sehingga akan meninggalkan kerusakan.
UU Perkebunan yang baru diharapkan memenuhi: pertama perubahan pradigma penyelenggaraan perkebunan, kedua menangani konflik sengketa lahan perkebunan, ketiga pembatasan penanaman modal asing, keempat kewajiban membangun dan menyiapkan sarana dan prasaranan perkebunan, keempat izin usaha perkebunan, kelima sistem data informasi dan sanksi bagi pejabat.

Tujuannya agar: pertama penyelenggaraan perkebunan dapat meningkatkan kesejahteraan dan kemakmuran rakyat. Kedua meningkatkan sumber devisa negara. Ketiga menyediakan lapangan kerja dan kesempatan usaha. Keempat meningkatkan produksi, produktifitas, kualitas, nilai tambah, daya saing, dan pangsa pasar. Kelima meningkatkan dan memenuhi kebutuhan konsumsi serta bahan baku industri dalam negeri. Keenam memberikan perlindungan kepada pelaku usaha perkebunan dan masyarakat, mengelola dan mengembangkan sumber daya perkebunan secara optimal, bertanggung jawab dan lestari. Ketujuh meningkatkan jasa perkebunan.

UU Perkebunan adalah standar pelaksanaan perkebunan yang berkeadilan. Tentunya dalam suatu aturan ada larangan dan ada juga kewajiban agar tujuan bersama bisa dicapai. Arah tujuan kebijakan larangan membuka lahan dengan 
cara membakar, sebagaimana di atur dalam Pasal 56 Ayat (1) tidak terlihat keterkaitannya dengan politik hukum UU Perkebunan terbaru secara langsung.

Membuka atau mengolah lahan dengan cara membakar dilarang, berhubungan dengan lingkungan hidup, bukan mengurangi nilai tambah perkebunan. Membakar lahan yang tidak tersistematis dan tanpa pembatasan akan menyebabkan bencana alam. Kerusakan lingkungan tidak mungkin untuk dihindari jika proses pembakaran tidak terkendali.

Tidak hanya membakar lahan, proses pembakaran apapun akan menghasilkan zat yang berbahaya bagi kehidupan mahkluk hidup jika berlebihan. Jika tidak terjadi keseimbangan di alam, kerusakan pasti terjadi. Pemanasan global akan semakin meningkat dan berakibat dengan perubahan iklim. Kualitas lingkungan hidup yang menurun akan mengancam kehidupan makhluk hidup, termasuk manusia.

Pasal 56 ayat 1 UU Perkebunan, sangat berkaitan dengan Undang-Undang Nomor 32 Tahun 2009 tentang Perlindungan dan Pengelolaan Lingkungan Hidup (UU PPLH). Setiap manusia membutuhkan lingkungan hidup yang baik dan sehat. Negara berkewajiban untuk memenuhi kebutuhan tersebut, karena hak untuk mendpatkan lingkungan hidup yang baik dan sehat adalah hak dari setiap warga negara Indonesia. Pasal 28H UUD 1945 sudah memberikan amanat tentang hak ini.

Pembangunan perekonomian nasional adalah hal yang utama dalam bernegara, namun pembangunan ekonomi tidak bisa melupakan lingkungan hidup. Ekonomi yang baik tidak akan berguna jika lingkungan hidup tidak baik dan sehat. Oleh sebab itu, pembangunan ekonomi dilakukan dalam jangka waktu yang tidak singkat, harus memiliki wawasan lingkungan yang baik. Awal dari pembangunan ekonomi yang baik dan sehat adalah Lingkungan yang baik dan sehat.

Pasal 56 ayat 1 UU Perkebunan adalah penekanan kembali tentang larangan membakar lahan dalam Pasal 69 ayat 1 huruf h UU PPLH, bahwa "setiap orang dilarang melakukan pembukaan lahan dengan cara membakar”. Penekanan kembali ini bertujuan untuk membuktikan secara hukum bahwa pembangunan perekonomian Indonesia memiliki wawasan lingkungan. Artinya negara bertanggung jawab untuk perekonomian yang baik bagi seluruh warganya tanpa mengurangi hak-hak warganya dalam mendapatkan lingkungan yang baik dan sehat.

\section{Pelaku usaha perkebunan dalam Pasal 56 ayat (1) UU Perkebunan}

Pasal 56 Ayat (1) jika dilihat sekilas, memberikan sinyal bahwa kata "setiap" 
pada teks Pasal menunjukkan tidak ada pengecualian. Adapun syarat pemberlakukannya: pertama orang tersebut sebagai Pelaku Usaha Perkebunan. kedua melakukan kegiatan membuka dan/atau mengolah lahan. Ketiga menggunakan metode membakar. Tiga syarat tersebut harus terpenuhi. Jika salah satunya ada yang tidak terpenuhi, maka Pasal 56 ayat 1 tidak bisa digunakan.

Apakah benar demikian, bahwa kata "setiap" pada teks Pasal tersebut tidak memberikan pengecualian?

Perkebunan yang dimaksud dalam UU Perkebunan adalah segala kegiatan pengelolaan sumber daya alam, sumber daya manusia, sarana produksi, alat dan mesin, budi daya, panen, pengolahan, dan pemasaran terkait Tanaman Perkebunan . Perkebunan memiliki perencanaan yang dilakukan oleh Pemerintah Pusat, Pemerintah Provinsi dan Pemerintah Kota . Melalui perencanaan, maka tidak semua wilayah bisa dijadikan perkebunan. Hanya perkebunan yang termasuk kedalam tata ruang wilayah perkebunan yang bisa dikategorikan perkebunan, sesuai dengan rencana tata ruang wilayah perkebunan yang sudah ditetapkan oleh pemerintah .

Pelaku Usaha Perkebunan yang dimaksud dalam Pasal 56 ayat 1 adalah pekebun dan/atau perusahaan Perkebunan yang mengelola Usaha Perkebunan . Pekebun yang menjadi pelaku usaha perkebunan adalah orang perseorangan warga negara Indonesia yang melakukan Usaha Perkebunan dengan skala usaha tidak mencapai skala tertentu . Perusahaan Perkebunan yang menjadi pelaku usaha perkebunan adalah badan usaha yang berbadan hukum, didirikan menurut hukum Indonesia dan berkedudukan di wilayah Indonesia, yang mengelola Usaha Perkebunan dengan skala tertentu .

Usaha Perkebunan yang diusahakan oleh pekebun dan perusahaan perkebunan adalah usaha yang menghasilkan barang dan/atau jasa Perkebunan. Jenis usaha perkebunan ada tiga, sebagai berikut: pertama usaha budi daya tanaman perkebunan yaitu kegiatan pratanam, penanaman, pemeliharaan tanaman, pemanenan, dan sortasi. Kedua usaha pengolahan hasil perkebunan, yaitu kegiatan pengolahan yang bahan baku utamanya Hasil Perkebunan untuk memperoleh nilai tambah. Ketiga usaha jasa perkebunan yaitu kegiatan untuk mendukung usaha budi daya tanaman dan/atau usaha Pengolahan Hasil Perkebunan .

Perusaahaan dalam menjalankan usahanya harus memiliki izin, seperti: pertama Izin Usaha Perkebunan untuk Budi daya (IUP-B) yang berbentuk izin tertulis dari pejabat yang berwenang dan wajib dimiliki oleh Perusahaan Perkebunan yang melakukan usaha budi 
daya Perkebunan . Kedua Izin Usaha Perkebunan untuk Pengolahan (IUP-P) yang berbentuk izin tertulis dari pejabat yang berwenang dan wajib dimiliki oleh Perusahaan Perkebunan yang melakukan usaha industri pengolahan hasil Perkebunan . Ketiga Izin Usaha Perkebunan (IUP) yang berbentuk izin tertulis dari pejabat yang berwenang dan wajib dimiliki oleh Perusahaan Perkebunan yang melakukan usaha budi daya Perkebunan dan terintegrasi dengan usaha industri pengolahan hasil Perkebunan .

Tidak setiap orang bisa melakukan usaha perkebunan. Usaha budi daya Tanaman Perkebunan dan/atau usaha Pengolahan Hasil Perkebunan hanya dapat dilakukan oleh Perusahaan Perkebunan. Syarat utamanya, Perusahaan untuk bisa melakukan dua usaha tersebut, harus memiliki hak atas tanah dan/atau izin Usaha Perkebunan .

Untuk memenuhi mendapatkan IUP perusahaan harus memenuhi syarat sebagai berikut:

(1). Izin lingkungan;

(2). Kesesuaian dengan rencana tata ruang wilayah;

(3). Kesesuaian dengan rencana Perkebunan;

(4). Untuk usaha budi daya Perkebunan harus mempunyai sarana, prasarana, sistem, dan sarana pengendalian organisme pengganggu tumbuhan,.

(5). Untuk usaha Pengolahan Hasil Perkebunan harus memenuhi sekurangkurangnya $20 \%$ (dua puluh perseratus) dari keseluruhan bahan baku yang dibutuhkan berasal dari kebun yang diusahakan sendiri.

Lahan yang dimaksud dalam Pasal 56 ayat 1 adalah lahan perkebunan yaitu bidang tanah yang digunakan untuk usaha perkebunan . Batasan luas maksimum dan luas minimum penggunaan lahan untuk usaha perkebunan ditetapkan oleh pemerintah pusat . Pembukaan lahan dan/atau pengolahan lahan harus melalui perencanaan yang disebut dengan Rencana Kerja Pembukaan dan/atau Pengolahan Lahan Perkebunan (RKPPLP). Pada RKPPLP memuat dokumen perencanaan kerja dalam melakukan pembukaan dan/atau pengolahan Lahan Perkebunan tanpa membakar . Tujuan dari RKPPLP untuk mencegah timbulnya kerusakan lingkungan hidup.

Pasal 56 ayat 1 juga memiliki sanksi pidana dan administrasi sebagaimana tertuang dalam Pasal 108 "Setiap Pelaku Usaha Perkebunan yang membuka dan/atau mengolah lahan dengan cara membakar sebagaimana dimaksud dalam Pasal 56 ayat (1) dipidana dengan pidana penjara palinglama 10 (sepuluh) tahun dan denda paling banyak Rp 10.000.000.000,00 
(sepuluh miliar rupiah)". Untuk mencegah terjadinya membuka dan/atau mengolah lahan dengan cara membakar dan terjadinya kebakaran di lahan dan/atau memadamkan api dilahan yang terbakar, maka setiap Pelaku Usaha Perkebunan juga berkewajiban memiliki sistem, sarana, dan prasarana pengendalian kebakaran lahan dan kebun .

Dari penjelasan yang cukup panjang di atas, maka terlihat bahwa pelaku usaha perkebunan bisa pekebun dan/atau perusahaan perkebunan. Tetapi hal yang harus dilihat bahwa dalam UU Perkebunan yang menjadi titik fokus pengaturannya lebih kepada perusahaan perkebunan sebagai pelaku usaha perkebunan. Sebagaimana "tidak setiap orang bisa melakukan usaha perkebunan yaitu Usaha budi daya Tanaman Perkebunan dan/atau usaha Pengolahan Hasil Perkebunan, karena hanya dapat dilakukan oleh Perusahaan Perkebunan" tertuang dalam Pasal 45 UU Perkebunan.

Kegiatan pratanam, penanaman, pemeliharaan tanaman, pemanenan, dan sortasi tentunya akan selalu dilakukan oleh seorang pekebun. UU Perkebunan menyebut kegiatan yang dilakukan oleh pekebun dengan "usaha budi daya tanaman perkebunan". Walaupun memenuhi unsur "usaha budidaya tanaman perkebunan", namun kegiatan dari pekebun tersebut tidak bisa dikategorikan sebagai "usaha perkebunan" dalam hal "usaha budi daya tanaman perkebunan" sebagaimana yang diatur dalam UU Perkebunan. Kegiatan pekebun secara umum merupakan kegiatan yang berhubungan dengan usaha perkebunan, namun UU Perkebunan berdasarkan Pasal 45 telah membatasi siapa yang bisa disebut pelaku usaha perkebunan.

Setiap pelaku usaha perkebunan juga berkewajiban memiliki sistem, sarana, dan prasarana pengendalian kebakaran lahan dan kebun. Pekebun bagaimana mungkin bisa memenuhi kewajiban tersebut? Sistem, sarana dan prasarana yang dimaksud dalam Pasal 56 ayat 2 UU Perkebunan, tentunya memiliki standar yang di atur oleh pemerintah. Pekebun yang memiliki modal kecil tidak akan bisa memenuhinya.

Izin perkebunan yang diwajibkan untuk pelaku usaha perkebunan, bisa dilihat fakta bahwa pekebun yang ada di Indonesia sebagian besarnya tidak memiliki izin tersebut. Pekebun tidak memiliki izin lingkungan. Pekebun pada umumnya tidak memiliki RKPPLP yang tentunya harus disetujui oleh pemerintah, agar pemerintah bisa melakukan fungsinya sebagai pengawas usaha perkebunan. Tujuan pengawasan agar tidak terjadi perusakan lingkungan.

Dilihat dari sisi denda maksimal Rp. 10.000.000.000 (sepuluh miliar rupiah) 
dan hukuman penjara maksimal 10 tahun, maka kejahatan lingkungan yang dilakukan tidaklah ringan. Sebagian besar pekebun tidak akan sanggup membayar denda maksimal, jika melakukan pembukaan dan/atau pengolahan lahan dengan cara membakar, karena dari sisi keuangan pekebun bukanlah pemodal besar.

Selain itu yang perlu diingat bahwa, hadirnya pasal 56 ayat 1 dalam UU Perkebunan memiliki keterkaitan dengan UU PPLH, Pasal 69 ayat 1 huruf h "setiap orang dilarang membuka dan/atau mengolah lahan dengan cara membakar", tetapi 69 ayat 1 tidak berdiri sendiri melainkan bergandengan dengan ayat 2 . Pasal 69 ayat (2) menyatakan, "Ketentuan sebagaimana dimaksud pada ayat (1) huruf $\mathrm{h}$ memperhatikan dengan sungguh sungguh kearifan lokal di daerah masing-masing". Pada ayat (1) huruf h Pasal 69 memang dilarang membuka lahan dengan cara membakar, namun pada ayat (2) ada penekanan bahwa penegakan hukum terhadap larangan membakar lahan harus memperhatikan kearifan lokal yang ada di daerah. Dipertegas lagi pada penjelasan ayat (2) bahwa, "kearifan lokal yang dimaksud dalam ketentuan ini adalah melakukan pembakaran lahan dengan luas lahan maksimal 2 hektar per kepala keluarga untuk ditanami tanaman jenis varietas lokal dan dikelilingi oleh sekat bakar sebagai pencegah penjalaran api ke wilayah sekelilingnya.

Oleh sebab itu, kata "setiap" pada Pasal 56 ayat 1 tidak termasuk pekebun, walaupun pekebun dikategorikan pelaku usaha perkebunan. Pekebun sebagai pelaku usaha perkebunan bukanlah sebagaimana yang dimaksud dalam UU Perkebunan melainkan dalam kategori umum saja. Kata "setiap" pada Pasal 56 ayat 1 hanya berlaku bagi perusahaan perkebunan, karena yang bisa melakukan usaha perkebunan dalam hal usaha budidaya tanaman perkebunan hanyalah perusahaan perkebunan.

\section{PENUTUP}

Uraian diatas dapat disimpulkan bahwa: pertama Pengaturan larangan membuka dan/atau mengolah lahan dengan cara membakar dalam Pasal 56 ayat 1 adalah bentuk komitmen pemerintah dalam membangun perekonomian Indonesia dengan perkebunan berwawasan lingkungan yang relevansi dengan UU PPLH. Kedua pada UU Perkebunan tidak setiap orang menanam atau mememiliki tanaman musiman dan membuka atau mengolah lahan dengan cara membakar bisa dikategorikan sebagai pelaku usaha perkebunan yang bisa dipidana sebagaimana dimaksud dengan Pasal 108 jo Pasal 56 ayat 1 . Kata "setiap pelaku usaha perkebunan" yang dimaksud dalam UU 
Perkebunan adalah perusahaan perkebunan, bukan pekebun".

Oleh sebab itu hal yang disarankan kepada pemerintah sebagai berikut: perlu sosialisasi terhadap penegak hukum mulai dari lembaga Kepolisian, Kejaksaan dan Kehakiman terhadap arah kebijakan negara terkait: pertama pelarangan mebuka lahan dengan cara membakar di dalam UU Perkebunan dan kaitannya dengan lingkungan hidup, kedua tentang tidak semua pekebun yang bisa dikategorikan sebagai pelaku usaha perkebunan sebagaimana yang dimaksud dalam Pasal 56 ayat (1) jo Pasal 108 UU Perkebunan.

Perlu dibuat aturan turunan yang bersifat internal dilingkungan lembaga kepolisian, kejaksaan dan kehakiman oleh atasan tertinggi lembaga tersebut sebagai pedoman para penegak hukum bagi para penegak hukum dalam menjalankan tugasnya terkait: pertama pelarangan mebuka lahan dengan cara membakar di dalam UU Perkebunan dan kaitannya dengan lingkungan hidup, kedua tentang tidak semua pekebun yang bisa dikategorikan sebagai pelaku usaha perkebunan sebagaimana yang dimaksud dalam Pasal 56 ayat (1) jo Pasal 108 UU Perkebunan.

\section{DAFTAR PUSTAKA}

Amirin, Tatang M. Menyusun Rencana Penelitian. Jakarta: PT Raja Grafindo Persada, 1995.

Bungin, Burhan. Analisis Data Penelitian Kualitatif, Pemahaman Filosofis Dan Metodologis Ke Arah Penguasaan Model Aplikasi. Jakarta: Raja Grafindo Persada, 2003.

Ediwarman. "Monograf Metodologi Penelitian Hukum (Panduan Penelitian Tesis Dan Disertasi)." Universitas Muhammadiyah Sumatera Utara, 2010.

Faridhi, Adrian. "Penguji Peraturan PerundangUndangan Tunggal Keniscayaan.” Jurnal Mercatoria 10, no. 2 (2017): 180-96. https://doi.org/10.31289/mercatoria.v10i2. 1202.

Kahmad, Dadang. Metode Penelitian Agama. Bandung: CV Pustaka Setia, 200AD.

Sagama, Suwardi. "Analisis Konsep Keadilan, Kepastian Hukum Dan Kemanfaatan Dalam Pengelolaan Lingkungan.” MAZAHIB: Jurnal Pemikiran Hukum Islam XV, no. 1 (December 15, 2016): $20-41$. https://doi.org/10.21093/mj.v15i1.590.

Kejaksaan Negeri Rokan Hulu, P-29, Surat Dakwaan No. Reg. Perkara.: PDM148/PSP/11/2019,

Kejaksaan Negeri Rokan Hulu, P-42, Surat Tuntutan No. Reg. Perk.: PDM148/Psp/11/2019

Kejaksaan Negeri Kepulauan Meranti, P-42, Surat Tuntutan No Reg Perkara : PDM57 /SLP/ $04 / 2020$

LBH Pekanbaru, Resume Perkara Pidana 
Nomor : 187/Pid.B/2020/PN.Bls An

Terdakwa Rustam Bin. Alm. Kartawirya

Pada Pengadilan Negri Bengkalis,

Undang-Undang Dasar Negara Republik Indonesia Tahun 1945

Undang-Undang Nomor 32 Tahun 2009 tentang

Perlindungan dan Pengelolaan

Lingkungan Hidup

Undang-Undang Republik Indonesia Nomor 39
Tahun 2014 tentang Perkebunan

Peraturan Menteri Pertanian Republik Indonesia Nomor 05/Permentan/KB.410/1/2018 Tentang Pembukaan Dan/Atau Pengolahan Lahan Perkebunan Tanpa Membakar 